\title{
BANK SPECIFIC FACTORS AFFECTING THE EFFICIENCY OF REGIONAL DEVELOPMENT BANKS
}

\author{
Anneke Puspasari ${ }^{1}$, D.S. Priyarsono ${ }^{2}$, Hendro Sasongko ${ }^{3}$ \\ ${ }^{1,2}$ School of Business, IPB University, Bogor, Indonesia \\ ${ }^{3}$ Faculty of Economics, Pakuan University, Bogor, Indonesia \\ E-mail: puspasarianneke@yahoo.com
}

\begin{abstract}
Regional Development Banks (RDB) are part of the banking industry which has an important role in regional development. Therefore, RDB performance is important to be evaluated, and efficiency is an important indicator in measuring performance. The purpose of this study is to analyze the efficiency of the Regional Development Bank (RDB) in Indonesia and the internal factors that influence efficiency. Based on data of 26 RDBs in the study from 2011Q1 to 2019Q4, this study uses Data Envelopment Analysis (DEA), and the Tobit regression to investigate the determinants of technical efficiency. This analysis aims to explain the variations in calculated efficiencies to a set of internal explanatory variables. The results showed that most RDBs were technically inefficient during the study period. Furthermore, the internal variables that affect are size, capital adequacy ratio (CAR), loan to deposit ratio (LDR), return on asset (ROA), Listed Bank.
\end{abstract}

Keywords: bank specific factors, Data Envelopment Analysis (DEA), regional development bank, technical efficiency, Tobit Model

\section{ARTICLE INFORMATIONS}

Article histiry: submitted: Augustus 18, 2020; revised: November 15, 2020; accepted: November 28, 2020

JEL Classifiction: G20, G21

How to cited: Puspasari, A, et al. (2020). Bank Specific Factors Affecting The Efficiency of Regional Development Banks. JIMFE (Jurnal Ilmiah Manajemen Fakultas Ekonomi), 6(2), 171-186. https://doi.org/10.34203/jimfe.v6i2.2325

Copyright@2020. JIMFE (Jurnal IImiah Manajemen Fakultas Ekonomi) Universitas Pakuan

\section{INTRODUCTION}

The financial sector plays an important role in the economy of a country. In Indonesia, the financial sector especially the banking industry has a dominant role. It can be seen from the total asset of the banking industry compared to other institutions of financial services is $76.99 \%$ (Financial Services Authority, 2019). The important role of the banking industry as intermediary institutions will affect national economic growth so that banking performance needs to be considered for its stability and efficiency (Sathye, 2012). Efficiency is one of the parameters of performance that is quite popular and an important measure of bank operational conditions and is one of the key indicators of a bank's success, individually after comparing it with the entire banking industry (Wheelock and Wilson, 1995).

One of the banks in the spotlight in Indonesia is the Regional Development Bank (RDB) that RDB is currently not developing as rapidly as Conventional Banks (Sutanto, 2015). RDB's contribution to total assets and funds compared to national commercial banks is relatively low at $8,38 \%$ and $8,41 \%$ (Financial Services Authority, 2019). RDB is part of the national banking industry which has an important role, especially in regional development. RDB was established in 1962 based on Law No. 13 of 1962 concerning Basic Provisions for Regional Development Banks. The establishment of the RDB is intended to provide funding for the implementation of regional development within the framework of 
National Development. Based on the Decree of the Minister of Home Affairs (Kepmendagri) No. 62 of 1999 concerning the guidelines for the organization and work procedures of the Regional Development Bank, the function of RDB is (1) Driving the creation of economic growth and regional development, (2) Regional cash holders and/or saving money regions and (3) one source of regional original income.

RDB is a Regional Government-owned company that is highly dependent on the Regional Government (Yusuf, 2018). Dependence of RDBs on local governments is an obstacle for RDBs in developing performance and pushing RDBs to be inefficient due to the high intervention from the local government. The existence of political intervention pushes banks to become less efficient and makes it difficult for banks to compete with other commercial banks (Hadad et al., 2012). RDB's failure will have a systemic impact on the regional economy (Yonnedi and Rahman Panjaitan, 2019).

The role of RDB which is quite important in regional economic development as an intermediary institution encourages RDB to be able to improve its performance (Abidin, 2009). In 2015, Financial Services Authority (FSA) launched in RDB Transformation program. Transforming RDB has a vision of becoming a bank that is highly and powerfully engineered and contributes significantly to sustainable growth and equitable distribution of the regional economy. This program will further develop the overall RDB by strengthening the foundation through good governance, business and risk management so that going forward the RDB will become a more competitive, stronger, and contributive bank for regional development. One attempt to encourage RDB to be more competitive is by increasing efficiency through optimizing the internal factors of RDB.

Efficiency is one of the most important indicators in measuring bank performance. Recent research shows that efficiency is an important factor in banking competition where efficient banks have competitive advantages and lower costs than inefficient banks (Spong et al., 1995). With a higher level of efficiency, banking performance will be better in allocating financial resources which will later affect increasing investment and economic growth (Weill, 2003). Indicators that indicate bank efficiency can be shown through the ratio of operating costs to operating income (BOPO) and net interest margin (NIM). NIM RDBs still show a fairly high figure of 5,95\% in 2019 although it has decreased compared to 2011 of $8,1 \%$. The ideal NIM ratio is $5 \%$. BOPO RDB also showed an increase. In 2019 it was 79,56\%, an increase compared to 2011 at $79,14 \%$. This condition indicates a decrease in efficiency at the RDBs. Measurement of efficiency cannot only be based on financial ratios. The calculation of efficiency using financial ratios is inaccurate (Hadad et al., 2003). Firdaus dan Hosen (2014) argue that the measurement of efficiency using a BOPO (operational expenses to operational income) ratio does not describe of efficiency of a bank because the calculation of efficiency using a BOPO ratio is partial efficiency. Efficiency will be clearer if it is related to the concept of output-input comparison not only with partial calculations (Berger and Humphrey, 1997).

According to Berger and Humphrey (1997), measuring efficiency can use frontier analysis. One of the functions of frontier analysis is that it can describe the efficiency of industry, rankings in the company, or examine the relationship between efficiency measures and different efficiency techniques applied. In addition, through this method, it can be seen what variables cause a bank to be inefficient. Firdaus and Hosen (2014) used Data Envelopment Analysis (DEA) approach, stated that the efficiency level of Islamic banks in Indonesia has not yet reached the optimum level of Efficiency. Defung et al. (2016) showed that state-owned and foreign-owned in Indonesia more efficient than any group of banks. Wardhani and Mongid (2019) used the Stochastic frontier analysis (SFA) approach, 
found the efficiency of Islamic banks In Indonesia to be in the low and medium range.

Studies on bank efficiency in Indonesia especially RBDs, focus more on bank efficiency and without further examining the factors of bank efficiency (Endri, 2009; Abidin and Endri, 2009; Sutanto 2015; Fadhlullah, 2015). Endri (2009) found that the regional development banks did not play its optimal role as the intermediary institution and efficiency performance did not achieve the level of maximum (100\%). Abidin and Endri (2009) used Data Envelopment Analysis (DEA) approach stated that the big-asset of BPD are found to be more efficient than the middle and small asset. Sutanto (2015) shows that RDBs have not been efficient yet that the average is $93,2 \%$. Fadhullah (2015) focused on Islamic RDBs using Stochastic Frontier Analysis (SFA) approach, added that the average efficiency rate of Islamic regional banks is $53,21 \%$.

The measurement of bank efficiency is influenced by various factors. According to Widiarti et al. (2015), bank efficiency is affected by the ratio of non-performing loans (NPL), loan to deposit ratio (LDR), bank size, cost efficiency ratio (CER), and capital adequacy ratio (CAR). Gross domestic product (GDP), interbank money market interest rate volatility, overhead cost $(\mathrm{OHC})$, market share, credit channeled also affects bank efficiency (Muljawan et al., 2014). Firdaus and Husen (2013) conducted research related to the efficiency of Islamic commercial banks showing that the factors that influence total assets of Islamic commercial banks, return on assets $(R O A)$, return on equity (ROE), and the number of branches affects efficiency. According to Ghofur dan Sukmaningrum (2018) good corporate governance also affects bank efficiency.

Based on the explanation above, this study aims to examine the level of efficiency of RDBs in Indonesia and analyze the internal factors that affect bank efficiency.

\section{LITERATURE REVIEW BANK EFFICIENCY}

Efficiency is one of the performance parameters which theoretically becomes the basis for the performance of a company. Efficiency is defined as the ratio between a bank's ability to use input and output. The amount of output produced per unit of input shows great efficiency, while the maximum output produced per unit of input shows optimal efficiency (Sherman and Zhu, 2006; Hasibuan, 1994). There are 3 factors that cause efficiency, namely (1) if the same input produces a larger output, (2) a smaller input produces the same output, and (3) a larger input produces a larger output (Gordo, 2013). Measurement of efficiency determines how a company can maximize output and profits by minimizing costs (Mokhtar et al., 2008). The concept of efficiency was first proposed by Farrell (1957) who stated that the concept of measuring efficiency can take into account more than one input and output. The efficiency of a company consists of two components, namely technical efficiency, and allocative efficiency. Technical efficiency shows the company's ability to achieve the maximum possible output from several inputs, while allocative efficiency shows the company's ability to use inputs with the optimal proportion at a certain input price level. The two components are then combined to produce a measure of total efficiency or economic efficiency.

Measurement of efficiency can be done using two approaches, namely parametric and non-parametric approaches (Coelli, 1996). According to Berger and Mester, 1997 that the parametric approach is divided into the Stochastic Frontier Approach (SFA), Thick Frontier Approach (TFA), and Distribution Free Approach (DFA) methods. While the nonparametric approach uses a non-stochastic approach and tends to combine disturbance and inefficiency in measuring efficiency. This approach is known as the Data Envelopment 
Analysis (DEA) method. This study uses the Data Envelopment Analysis (DEA) method, in measuring the level of operational efficiency (Hadad et al., 2012; Sufian et al., 2016; Eyceyurt Batir et al., 2017). The DEA method is a method for calculating the ratio of output to input ratios for all units compared in a population. According to Hadad et al. (2003) the DEA method can obtain more accurate results than using financial ratio analysis.

\section{BANK FACTORS OF TECHNICAL EFFICIENCY}

Capital Adequacy Ratio (CAR) shows the ability of capital owned by banks to be able to survive. Banks with high capital levels are technically more efficient and have sufficient reserves to minimize the impact of increased credit risk (Isik and Hassan, 2003; Casu and Molyneux, 2003). The higher capital owned by a bank will increase efficiency (Pasiouras, 2008; Mamatzakis et al., 2016; Rosman et al., 2014). However, some research also shows that lower bank capital will increase efficiency (ARIFF and CAN, 2008; Girardone et al., 2004).

Non-Performing Loan (NPL) which is a proxy of credit risk. The more efficient bank has better credit quality or a relatively small NPL value so that there are no additional costs in dealing with bad loans will reduce efficiency (Hughes and Mester, 1993; Garza-García, 2012, Karim et al., 2010; Firdaus and Hosen, 2014; Buğan and Ata, 2016). According to Muljawan et al., 2014, NPL has a negative and insignificant influence because the credit risk will cause banks to tighten profit opportunities and will reduce their operational efficiency.

Return on Assets (ROA) is a proxy of banking profitability. Research by Casu and Molyneux (2003), Garza-García, (2012) shows that profitability ratios (ROA) affect bank efficiency. Contrary to the results of the study of Hou et al. (2014) that efficiency and profitability have a negative relationship.

Loan to Deposit Ratio (LDR) is a proxy of liquidity. The higher the lending, the greater the bank's profit opportunities, so that banks can increase their business scale and efficiency
(Vu and Turnell, 2011). Credit is the main source of income, so the higher income can reflect banks more efficiently, although credit extended by banks will depend on the development of credit risk itself (NonPerforming Loans) (Garza-García, 2012).

NIM (Net Interest Margin) is another important factor of bank efficiency. NIM reflects the spread between interest income and interest expense. NIM has a negative relationship with efficiency. A High NIM indicate that the banks impose high borrowing costs to borrowers, which causes the bank difficulty in channeling loans. Debtors with high loan rates tend to have poor creditworthiness, thus increasing non-performing loan. A high level of NIM is related to high inefficiency (Claeys and Vander Vennet, 2008). Negative relationships occur among others if the level of banking competition is low and can cause bank efficiency to be low (Muljawan et al., 2014).

Banks that have a greater asset value tend to be able to pay lower input costs than competing banks so that it affects efficiency (Bonin et al., 2005; Hauner, 2005; Sufian, 2009; Buğan and Ata, 2016). However, several studies prove that the smaller of the size, the better the efficiency (Hou et al., 2014; Ariff and Can, 2008).

Bank third-party deposits consist of savings, current accounts, and time deposits. Deposits are components of third party deposits which are expensive because they have a higher interest rate compared to savings and current accounts. The higher the deposit, the more interest expense paid will increase so that it will have an impact on efficiency.

Good Corporate Governance (GCG) is bank governance that applies the principles of openness, accountability, responsibility, independence, and fairness. According to Peni and Vähämaa, 2012 good corporate governance (GCG) has a positive effect on profitability. In contrast to the research results of Tobing et al., 2013, the implementation of GCG has a significant effect on competitiveness, namely productivity, 
profitability, and market valuation, but not on the BOPO ratio (efficiency).

Initial Public Offering (IPO) or offering of shares to the public is the sale of shares of a public company to the public or known as going public or listed. Banks with go public status affect efficiency. Exchange-listed banks tend to be more efficient than private banks (Berger and Humphrey, 1997; Casu and Molyneux, 2003). In contrast to the research results of Altunbas et al. (2001) that banks that do not go public are more efficient than banks that go public.

\section{METHODOLOGY}

\section{Data and Variable}

This research is a quantitative descriptive to 26 RDBs in Indonesia during the period 2011012019Q4. Variable input-output combination to measure the efficiency level of an individual bank consists of inputs: deposits, interest expenses, and non-interest expenses; output: loans, interest income, and net non-interest income.

\section{Data Envelopment Analysis}

Data Envelopment Analysis (DEA) is a nonparametric mathematical program used for frontier estimation. DEA in the research of Charnes et al. (1978) is a measure of efficiency for each decision-making unit (DMU) which is the maximum ratio between weighted output and weighted input. Each weight used in the ratio is determined by the limitation that the same ratio for DMU must have a value of less than one or equal to one. If the efficiency score is $100 \%$, meaning that the DMU no longer wastes the use of its inputs and outputs. Besides, DMU is inefficient if the efficiency value is less than $100 \%$, which means that the bank is still not able to optimally utilize its production capabilities. In the DEA, the relative efficiency score will be obtained between each DMU that is the object of research. In addition to producing efficiency values for each DMU, DEA also shows units that are a reference for inefficient units. DEA is very effective to be used to measure the performance of DMUs which in operation involve a lot of inputs and outputs.

Efficiency of $D M U=\frac{\sum_{k=1}^{n} \mu_{k} y_{r j}}{\sum_{i=1}^{m} v_{i} x_{i j}}$

Subject to:

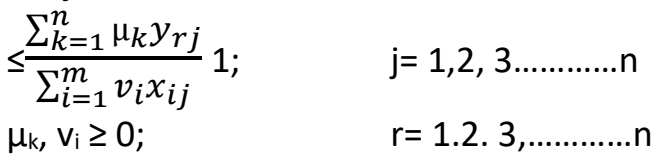

Information:

$\mathrm{k}=\mathrm{DMU}$

$\mathrm{m}=$ number of inputs

$\mathrm{n}=$ number of outputs

$x i j=i D M U ~ i$ input value $j$

$y r j=r$ DMU output value $j$

$\mu \mathrm{k}=$ weight of DMU $\mathrm{k}$ for the evaluated DMU

$\mathrm{vi}=\mathrm{DMU}$ weight $\mathrm{j}$ for the calculated DMU

Two models form the basis of DEA measurements, namely the Charnes, Cooper, and Rhodes (CCR) models and the Banker, Charnes, and Cooper (BCC) models. DEA calculations using the CCR model are based on the constant return to scale (CRS) assumption, while the BCC model is based on the variable return to scale (VRS) assumption. In the CCR model, each DMU will be compared to the existing DMU, with the assumption that the internal and external conditions are the same. This model assumes that the ratio of the addition of input and output is proportional to the optimal scale, meaning that the addition of input causes the addition of the same amount of output. The BCC model is a development of the CCR model. This model assumes that the company does not or has not yet operated at an optimal scale. The assumption of this BCC model is the ratio of the addition of input and output varies. The addition of inputs causes the addition of output with varying proportions.

The CCR model calculates efficiency by comparing output weights to input weights per each DMU unit and this model combines 
technical efficiency and scale efficiency calculations for each DMU. CCR modeling allows each DMU to determine the weighting of each input and output. However, due to imperfect competition, limited funds, and others, DMU did not operate optimally. It is assumed that $x_{i}$ and $y_{r}$ respectively represent inputs and outputs with indices $i=1,2, \ldots, I$ and $r=1,2, \ldots, R$. If $u$ and $v$ are respectively the weights of inputs and outputs, then respectively each DMU has input and output weights.

Maximization $\theta=\frac{\sum_{r=1}^{S} u_{r} y_{r o}}{\sum_{i=1}^{m} v_{i} x_{i o}}$

Subject to $: \frac{\sum_{r=1}^{S} u_{r} y_{r j}}{\sum_{i=1}^{m} v_{i} x_{i j}} \leq 1$,

$u_{r} \geq 0 ; \mathrm{r}=1,2, \ldots, \mathrm{s} ; v_{i} \geq 0 ; \mathrm{i}=1,2, \ldots, \mathrm{m} ; \mathrm{j}=1$, $2, \ldots, \mathrm{n} ; y_{r j} \geq 0 ; \mathrm{j}=1, \ldots ., \mathrm{n}$.

Where:

$\boldsymbol{x}_{\boldsymbol{i}}=$ input value to 1 in unit $\mathrm{j}$

$v_{i}=$ weighting for input to $i$

$y_{r j}=$ output value to $r$

$u_{r}=$ weighting for input to $i$

The BCC model is a model developed by Banker et al. (1984). The formulated model is based on the results of the modification of the CCR model which evaluates a limit on each DMU evaluated. The BCC development is a dual model of the DEA model, stated.

Maximization $\theta_{B}=\frac{\sum_{r=1}^{S} u_{r} y_{r j}}{\sum_{i=1}^{m} v_{i} x_{i j}}$ (3)

Subject to: $\frac{\sum_{r=1}^{S} u_{r} y_{r j}}{\sum_{i=1}^{m} v_{i} x_{i j}} \leq 1$,

$u_{r} \geq 0 ; \mathrm{r}=1,2, \ldots, \mathrm{s} ; v_{i} \geq 0 ; \mathrm{i}=1,2, \ldots, \mathrm{m} ; \mathrm{j}=1$, $2, \ldots, \mathrm{n} ; y_{r j} \geq 0 ; \mathrm{j}=1, \ldots ., \mathrm{n}$.

Where:

$\boldsymbol{x}_{i j}=$ input value to 1 in unit $\mathrm{j}$

$v_{i}=$ weighting for input to $i$

$y_{r j}=$ output value to $r$

$u_{r}=$ weighting for input to $i$
The BCC model has fewer decision variables than the CCR model, namely $\lambda j=1,2$, ..., n. To obtain a special set of weights per DMU for each input and output. BCC model is a DEA model with the principle of Variable Returns to Scale (VRS). The DEA-CRS program can be easily modified into the DEA-VRS model by only adding convexity constraints, namely $\Sigma$ $\lambda \mathrm{j}=1$. This study using the VRS model in which an evaluation of the DMU is done by overall efficiency with the assumption that all DMUs are operating at an optimal scale.

\section{Tobit Model}

Efficiency scores obtained using DEA (first stage) will be analyzed with several other variables using the Tobit regression (second stage). At this stage, an analysis of factors that influence efficiency will be carried out. The Tobit Regression assumed that the independent variables have an infinite value (non-censored) and the dependent variable has a censored value. The use of the Tobit regression is due to the value of the dependent variable, namely technical efficiency which lies between 0 and 1 . The equations of the model are as follows:

EFFit $=\alpha+\beta_{1} C_{\text {CAR }}+\beta_{2} L_{\text {LD }}+\beta_{3}$ NIM $_{i t}+\beta_{4}$ NPL $_{i t}$ $+\beta_{5} \mathrm{ROA}_{i t}+\beta_{6} \mathrm{SIZE}_{\mathrm{it}}+\beta_{7} \mathrm{DEP}$ it $+\beta_{8}$ $\mathrm{GCG}_{\mathrm{it}}+\beta_{9}$ Listed $_{\mathrm{it}}+\varepsilon$ (4)

Where: EFF: Banking Efficiency, Size: Total Asset Logarithm, CAR: Capital Adequacy Ratio, LDR: Loan Deposit Ratio, NPL: Non-Performing Loan, ROA: Return on Assets, NIM: Net Interest Margin, DEP: Composition of Deposit to third party deposits, GCG: Good Corporate Governance, Listed Bank: go public.

\section{RESULT}

The Measurement of Efficiency by Data Envelopment Analysis

Measuring of efficiency of the first stage RDB uses a non-parametric approach with the DEA method. The assumptions used in this study are VRS (variable return to scale) because the 
internal and external conditions of RDBs are relatively different. The addition of input causes the additional output of a different amount. VRS is suitable for banking industry activities (Irawati, 2008). Besides, this study uses an input-oriented intermediation approach because the input is primary decision variable (Coelli et al., 1998).

\section{The Average of Efficiency RDBs in period 2011Q1-2019Q4}

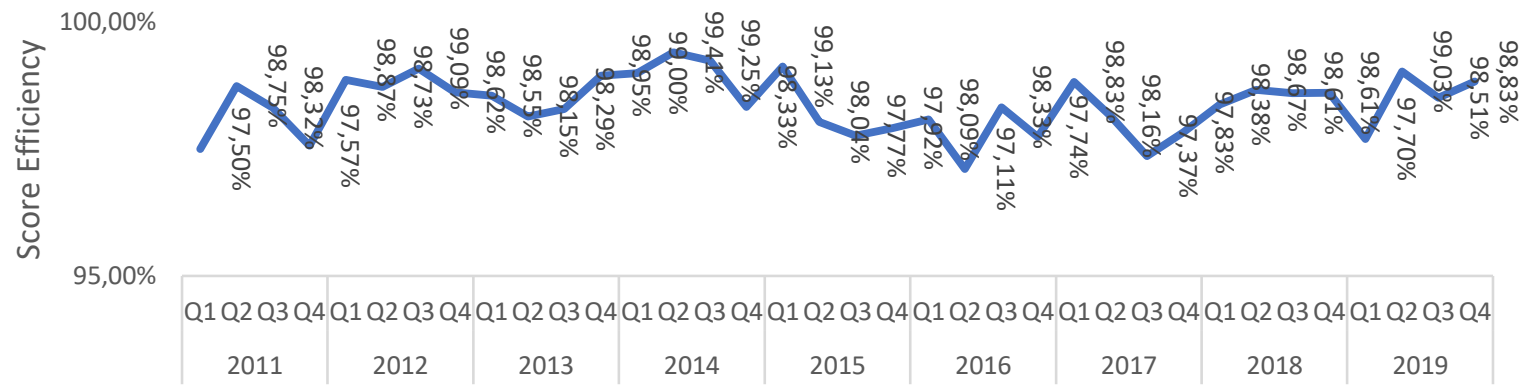

Figure 1. The average level of Efficiency RDBs in period 2011Q1-2019Q4

Source: Output DEA

Figure 1 shows the average efficiency level of 26 RDBs each quarter per year based on the DEA. The movement of efficiency in the period 2011Q1-2019Q4 has fluctuated. An unstable economic condition is one of the obstacles to increasing its efficiency. In general, RDB in Indonesia operates at an average efficiency level of $98.39 \%$. The highest level of efficiency occurred in 2014Q3 with a score of $99,41 \%$. There was an increase in the RDB's technical efficiency score from $97,50 \%$ in 201101 to $98,83 \%$ in 201904 . This indicates an increase in efficiency in the RDB. Besides, there was a decrease in the level of efficiency in 2015-2016. A fairly high decline occurred in the second quarter of 2016 with an efficiency level of $97,11 \%$. This occurred due to unstable economic conditions and policies pursued by Bank Indonesia to reduce the impact of the global crisis that was starting to have an impact on Indonesia.

Based on the results of RDBs efficiency measurements, it shows that the efficiency of RDBs that reaches $100 \%$ is not consistent every year (table 1). There are 7 RDBs or $26,92 \%$ which are consistently categorized as the most efficient RDB with an optimal efficiency level of
$100 \%$ compared to other RDBs, namely Bank Jabar Banten, Bank Jatim, Bank Kaltim, Bank Bali, Bank Papua, Bank Sulteng, and Bank Sultra. RDB that has reached an optimal level of efficiency means that RDB has been able to optimize all its resources. RDBs that have achieved an optimal efficiency score will become a benchmark for other RDBs. There are 19 RDBs or $73,08 \%$ which are categorized as low-efficiency levels with a score less than $100 \%$, namely Bank DKI, Bank DIY, Bank Jateng, Bank Jambi, Bank Aceh Syariah, Bank Sumut, Bank Riau, and Kep. Riau, Bank Sumselbabel, Bank Lampung, Bank Kalsel, Bank Kalbar, Bank Sulselbar, Bank NTB, Bank NTT, Bank Maluku, and Bank Bengkulu. This shows that the RDB has not been able to optimize its resources and does not pay attention to business continuity. The management should more focus on bank efficiency to make sustainable and healthy of RDBs.

The research by Abidin and Endri (2009), Yonnedi and Panjaitan (2019), show that the number of RDBs at optimal efficiency levels is quite low. Defung et al. (2018) also show that most RDBs are technically inefficient where the efficiency measure is below the efficiency limit. 
Anneke Puspasari: Bank Specific Factors ...

When compared with other bank groups, based on the results of research by Hadad et al. (2003) in 1995-2003, it was concluded that RDB was included in the inefficient bank group.

Table 1. Average Level of efficiency RDBs In 2011Q1-2019Q4

\begin{tabular}{lclclc}
\hline \multicolumn{1}{c}{ Bank Name } & $\begin{array}{c}\text { Efficiency } \\
\text { Score }\end{array}$ & Bank Name & $\begin{array}{c}\text { Efficiency } \\
\text { Score }\end{array}$ & Bank Name & $\begin{array}{c}\text { Efficiency } \\
\text { Score }\end{array}$ \\
\hline Bank Jabar Banten & $100,00 \%$ & Bank Riau & $97,11 \%$ & Bank NTB & $98,43 \%$ \\
Bank DKI & $98,74 \%$ & Bank Sumselbabel & $94,95 \%$ & Bank Bali & $100,00 \%$ \\
Bank DIY & $95,73 \%$ & Bank Lampung & $95,89 \%$ & Bank NTT & $99,18 \%$ \\
Bank Jateng & $99,65 \%$ & Bank Kalsel & $93,70 \%$ & Bank Maluku & $98,64 \%$ \\
Bank Jatim & $100,00 \%$ & Bank Kaltim & $97,65 \%$ & Bank Papua & $100,00 \%$ \\
Bank Jambi & $99,97 \%$ & Bank Kalbar & $96,70 \%$ & Bank Bengkulu & $97,83 \%$ \\
Bank Aceh & $97,24 \%$ & Bank Kalteng & $100,00 \%$ & Bank Sulteng & $100,00 \%$ \\
Bank Sumut & $98,98 \%$ & Bank Sulselbar & $99,97 \%$ & Bank Sultra & $100,00 \%$ \\
Bank Sumbar & $98,91 \%$ & Bank Sulutgo & $98,96 \%$ & & \\
\hline
\end{tabular}

Source: DEA Output

Based on the calculation of DEA on the average RDB efficiency level, BPD Kalsel is the lowest efficiency level average of 93,70\% to the other's RDB. The Bank Kalsel needs to develop interest expenses, non-interest expenses, and third party deposits. BPD Kalsel should decrease the input variable that is interest expenses 10,55\%, non-interest expenses $9,77 \%$, and third-party deposits $7,8 \%$. On the output side, Bank Kalsel needs to increase noninterest income by $25,35 \%$. Based on financial data, the proportion of non-interest income is compared to total assets at Bank Kalsel, respectively $0,51 \%$. When compared with national commercial banks, the proportion of non-interest income is $2,30 \%$. This shows that the operating income other than RDB interest is still relatively low. RDB needs to develop and optimize its products or services to increase non-interest income through an increase in fee-based income. The application of

\footnotetext{
${ }^{1}$ OJK Regulation No. 6 / POJK.03 / 2016 concerning Business Activities and Office Networks Based on Bank Core Capital contains a classification based on bank core capital divided into 4 BUKU (Commercial Banks Business Activities): BUKU 1 with core capital up to less from IDR 1 trillion, BUKU 2 with core
}

information technology can be an alternative to increasing RDB operating income.

The result of DEA shows that the highest potential for efficiency improvement is an increase in non-interest operating income. Figure 2 shows that non-interest income is $32 \%$. To increase non-interest income is by developing services to customers that can increase fee-based income, for example, transfer services, bank guarantees, letters of credit, payments. However, the development of these services still faces obstacles, especially in the RDB due to limited capital. Based on the grouping of commercial banks based on business activities, in 2019 shows that 21 RDBs are in $B^{\prime} K^{1} 1$ and BUKU 2. This condition affects the RDB's ability to develop business activities. RDB's business activities are limited under the core capital owned by RDB. Banks with BUKU 3 and BUKU 4 tend to have a wider range of business activities than BUKU 1 and

capital of at least IDR 1 trillion to less than IDR 5 trillion, BUKU 3 with core capital of at least IDR 5 trillion to less than IDR 30 trillion, and BUKU 4 with core capital of at least IDR 30 trillion. 
BUKU 2. Therefore, to develop RDB is through additional capital.

Potential Improvement of RDB

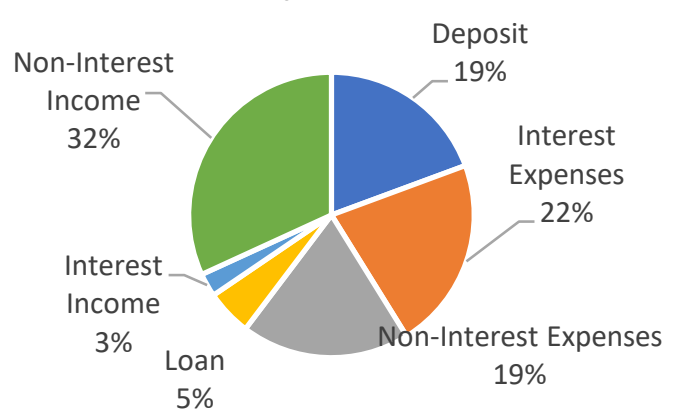

Figure 2. Potential Improvement of RDB
The Measurement of Bank Efficiency'a Factors Using the Tobit Model

The factors affecting bank efficiency are CAR, LDR, NIM, NPL, ROA, total asset (SIZE), the composition of time deposit to total deposits (DEP), Good Corporate Governance (GCG), and Listed Bank. Table 2 shows the descriptive statistics of these independent variables.

The Capital Adequacy Ratio (CAR) of RDB is good because it is still above the regulatory standard of $8 \%$. It shows that there are no capital adequacy problems on RDB. The RDBs have an average LDR of $77,28 \%$. It shows that the LDR of RDBs is required by a regulator which means RDBs are not expansive in terms of lending during the period Q1 2011-Q4 2019.

Table 2. Descriptive Statistic of Bank Factors of Efficiency During 2011Q1-2019Q4

\begin{tabular}{lccccc}
\hline \multicolumn{1}{c}{ Ratio } & Mean & Maximum & Minimum & Std. Dev. & Obs \\
\hline CAR (\%) & 19,95 & 38,25 & 9,57 & 4,48 & 936 \\
ROA (\%) & 3,12 & 8,89 & $-3,32$ & 1,18 & 936 \\
NPL (\%) & 2,73 & 19,93 & 0,13 & 2,44 & 936 \\
LDR (\%) & 77,28 & 128,43 & 34,69 & 14,25 & 936 \\
NIM (\%) & 7,51 & 23,92 & $-4,76$ & 2,03 & 936 \\
SIZE (Ln to Asset) & 16,41 & 18,58 & 13,96 & 0,85 & 936 \\
DEP (\%) & 34,94 & 72,39 & 2,75 & 13,19 & 936 \\
GCG & 2,41 & 3,00 & 1,00 & 0,52 & 936 \\
Listed Bank (Dummy & & & & & \\
Variable) & 0,00 & 1,00 & 0,00 & 0,22 & 936 \\
\hline
\end{tabular}

The RDBs have an average NIM of 7,51\%. The high NIM can be attributed to either low funding cost or high credit interest rate charged to borrowers. Credit quality as reflected of NPL shows that the average of RDBs is $2,73 \%$ (under the regulatory standard of 5\%).

Another quite good variable is ROA which has an average of $3,12 \%$. The high ROA indicated as high profitability of RBDs which means an effect on efficiency. The size of RDBs represented by total assets shows that the average of total assets categorized as BUKU 2. The average of RDB's total assets is Rp19.264 billion. Considering the average composition of time deposit to total deposit is $34,94 \%$. The largest funds of RDBs are savings that have a low rate of interest.
The average of RDB's Good Corporate Governance (GCG) during 2011Q1-2019Q4 is 2,41 . The maximum GCG is 3 . The variable for the listed bank uses a dummy variable, which is 1 for go public and 0 for banks that are not public. The average of the bank listed is 0,00 .

The result of the Tobit regression shown factors that affect the efficiency of RDB. Table 3 shows the internal factors that affect efficiency, including CAR, LDR, NIM, NPL, ROA, size (assets), and DEP, GCG, and Listed Bank.

The CAR has positively and significantly related to efficiency. This finding similar to research conducted by Lotto (2019), Das and Ghosh (2006) so that banks need to be encouraged to have sufficiently high capital capacity to minimize risk exposure and improve 
bank operational efficiency. Banks with high levels of capital have sufficient reserves to minimize the impact of increased credit risk (Isik and Hassan, 2003; Casu and Molyneux, 2003)

The LDR has positively and significantly related to efficiency. The high of the LDR shows the high of the lending that is potentially generating greater levels of interest income and enhancing bank profitability, thus the bank can increase business scale and efficiency $(\mathrm{Vu}$ and Turnell, 2011). Ally Z and Patel G (2014) also showed that the higher the ability of a bank to convert deposits into loans, the bank will be more efficient. However, Endri (2009) stated that the low of LDR indicated not all sources of funds channeled into credit. As consequence, the excess of liquidity banking was placed on Bank Indonesia Certificate (SBI) as an instrument that offers a fairly competitive return and risk-free. Besides, Muljawan et al (2014) stated that an increase in credit must still be accompanied by an increase in deposits because it will have an impact on liquidity risk, it will cause inefficiency.

The ROA has a positive effect on the efficiency of the RDB. The results of research related to Garza-García (2012) show that ROA has a positive effect on bank efficiency. Banks with high profitability ratios can attract customers so that Banks can increase the collection and distribution of funds (Ally and Patel, 2014; Maniati and Sambracos, 2017). Besides, banks with high profitability can manage assets more effectively and efficiently to reduce credit risk.

The variable of the size has a positive and significant effect on RDB efficiency. The greater the assets owned by the bank, then the bank can earn high profits (Santosa, 2018). The research similar to the results of Pasiouras (2008), Defung et al. (2016) that there is a positive relationship between total assets and bank efficiency. Large banks have a high level of efficiency because they have more ability to manage their resources. Besides, banks also tend to be able to pay lower input costs than their competing banks, thereby affecting efficiency levels by considering the services provided (Hauner, 2005; Sufian, 2009; Hassan et al., 2004; Maniati and Sambracos, 2017; Buğan and Ata, 2016).

Table 3. Bank Factors of Regional Development Bank's Efficiency During 2011Q1-2019Q4

\begin{tabular}{lcccl}
\hline Variable & Coefficient & Std. Error & z-Statistic & Prob. \\
\hline C & 0,866 & 0,03205 & 27,011 & 0,000 \\
CAR & 0,00040 & 0,00024 & 1,685 & $0.091^{* *}$ \\
LDR & 0,00044 & 0,00008 & 5,335 & $0,000^{*}$ \\
NIM & $-0,00074$ & 0,00074 & $-1,000$ & 0,317 \\
NPL & 0,00017 & 0,00056 & 0,305 & 0,760 \\
ROA & 0,008 & 0,001 & 5,468 & $0,000^{*}$ \\
SIZE & 0,003 & 0,0027 & 1,806 & $0,071^{* *}$ \\
DEP & $-0,00011$ & 0,0001 & $-1,139$ & 0,255 \\
GCG & 0,003 & 0,002 & 1,536 & 0,125 \\
Listed & 0,017 & 0,006 & 3,020 & $0,003^{*}$ \\
\hline
\end{tabular}

Sources: EViews Output

* Significance at $5 \%$

** Significance at $10 \%$

The NIM has a positive but not significant effect on the efficiency of RDB. This shows that
NIM does not make a significant contribution to the efficiency of RDB. Ally Z and Patel G (2014) 
there is a positive relationship between NIM and banking efficiency. Banks that have high profitability will tend to attract customers to place their funds and the quality of credit distributed is of good quality so this condition will affect bank efficiency. According to Muljawan et al (2014), banks can be more efficient by increasing NIM because it can reduce interest expense or increase interest income.

The NPL reflects the level of bank credit risk, which shows a negative and insignificant effect. Banks that have a high level of credit risk will tend to have a low level of efficiency (Carvallo and Kasman, 2005). A high NPL causes the bank to create a high allowance for impairment losses (CKPN) which will increase costs and reduce bank profitability so that efficiency decreases. However, RDB NPL is not significant to efficiency. This condition is due to the higher demand for credit from high NPLs, so banks tend to tighten their lending.

The variable composition of deposits against the composition of the comparison is negative and not significant. Deposits are an instrument for the placement of funds with high interest compared to savings and current accounts. The higher the composition of deposits on total party funds, the level of efficiency will decrease. High-interest costs will increase lending. Credit distribution will increase, but credit quality is poor. However, the composition of RDB's deposits to this efficiency was not significant because the interest rates determined by the RDB are adjusted to the applicable banking industry interest rates.

The variable Good Corporate Governance (GCG) has a positive but insignificant effect on the efficiency of BPD. This shows that improvements to the bank's GCG lead to an increase in costs which will reduce profits, thereby affecting efficiency levels. The insignificant effect of GCG measurement on efficiency is caused by the bank's GCG measurement which is still using bank self-assessment. The GCG assessment in this study uses the values obtained from bank publications.

The listed variable shows that banks that have been listed on the stock exchange have a positive and significant effect on efficiency. According to Hadad et al. (2012), listed banks tend to have better performance, but this relationship is relatively low. The results related to Casu and Molyneux (2003), Yin et al. (2015), Dianti (2019) banks that have chosen to go public are more efficient than banks that do not go public.

\section{CONCLUSIONS}

This study aims to analyze the efficiency of Regional Development Banks (RDB) in Indonesia and the internal factors that influence efficiency. The method used in this study uses a two-stage Data Envelopment Analysis (DEA). In the first stage, the efficiency of 26 RDBs was measured during the 2011Q12019 Q 4 period. The inputs used in this study are third party deposits, interest expenses, and non-interest expenses, while the output used is total credit, interest income, and non-interest income. In general, based on the results of DEA calculations, the technical efficiency of RDB has increased in the 2011Q1-2019Q4 period. There are 7 RDBs that relatively efficient with an optimal efficiency level of $100 \%$. The main cause of RDB inefficiency is non-interest income (output), while the input is the interest expense. One of the attempts to increase noninterest income is to increase capital. Limited capital in the RDBs causes restrictions on business activities. RDBs can utilize its capital to develop fee-based income products. The second stage shows the factors that influence efficiency in RDB using the Tobit model. Factors that have a positive and significant effect on RDB efficiency include Capital Adequacy Ratio (CAR), Loan Deposit Ratio (LDR), Return On Assets (ROA), Size, and listed bank.

The managerial implication in this research is that the Financial Services Authority 
Anneke Puspasari: Bank Specific Factors ...

(OJK) is expected to be able to encourage RDB and regional governments to increase their capital. The infcrease in the capital can encourage $\mathrm{RDB}$ to increase the scope of business activities and services to increase to encourage an increase in non-interest income. Besides, encouraging RDB to increase lending to all sectors both productive and consumptive so that it is expected to increase interest expense.

\section{REFERENCES}

Abidin, Z., and Endri. (2009). Kinerja Efisiensi Teknis Bank Pembangunan Daerah: Pendekatan Data Envelopment Analysis (DEA). Jurnal Akuntansi Dan Keuangan, 11(1), 21-29. https://doi.org/10.9744/jak.11.1.pp.2129.

Ally, Z., and Patel, G. N. (2014). Evaluating Efficiency of Commercial Banks in Tanzania and identifying efficiency drivers. IOSR Journal of Business and Management, 16(7), 50-64. https://doi.org/10.9790/487x-16745064.

Altunbas, Y., et al. (2001). Bank Ownership and Efficiency. Journal of Money, Credit and Banking, 33(4), 926. https://doi.org/10.2307/2673929.

ARIFF, M., and CAN, L. (2008). Cost and profit efficiency of Chinese banks: A nonparametric analysis. China Economic Review, 19(2), 260-273. https://doi.org/10.1016/j.chieco.2007.04 .001.

Berger, A. N., and Humphrey, D. B. (1997). International Survey and. European Journal on Operatinoal Research, 98(2), 175-212.

Berger, A. N., and Mester, L. J. (1997). Inside the black box: What explains differences in the efficiencies of financial institutions? Journal of Banking and Finance, 21(7), 895-947. https://doi.org/10.1016/S03784266(97)00010-1.

Bonin, J. P., et al. (2005). Bank performance, efficiency and ownership in transition countries. Journal of Banking and Finance, 29(1 SPEC. ISS.), 31-53. https://doi.org/10.1016/j.jbankfin.2004. 06.015.

Buğan, M. F., and Ata, H. A. (2016). Factors Affecting the Efficiency of Islamic and Conventional Banks in Turkey. Journal of Islamic Economics Banking and Finance, 12(1), 90-97. https://doi.org/10.12816/0028313.

Carvallo, O., and Kasman, A. (2005). Cost efficiency in the Latin American and Caribbean banking systems. Journal of International Financial Markets, Institutions and Money, 15(1), 55-72. https://doi.org/10.1016/j.intfin.2004.02. 002.

Casu, B., and Molyneux, P. (2003). A comparative study of efficiency in European banking. In Applied Economics, 35(17). https://doi.org/10.1080/0003684032000 158109.

Charnes, A., et al. (1978). Measuring the efficiency of decision making units. European Journal of Operational Research, 2(6), 429-444. https://doi.org/10.1016/03772217(78)90138-8

Claeys, S., and Vander Vennet, R. (2008). Determinants of bank interest margins in Central and Eastern Europe: A comparison with the West. Economic Systems, 32(2), 197-216. https://doi.org/10.1016/j.ecosys.2007.04 .001

Coelli, T. (1996). A guide to Deap version 2.1: A Data Envelopment Analysis (computer) Program. Retrieved grom Armidale, Australia).

Coelli T, et al. (1998). An introduction to efficiency and productivity. Analysis. Boston: Kluwer Academic Publishers.

Das, A., and Ghosh, S. (2006). Financial deregulation and efficiency: An empirical analysis of Indian banks during the post reform period. Review of Financial 
JIMFE (Jurnal Ilmiah Manajemen Fakultas Ekonomi) https://journal.unpak.ac.id/index.php/jimfe

Economics, 15(3), 193-221. https://doi.org/10.1016/j.rfe.2005.06.00 2

Defung, F., et al. (2016). Has regulatory reform had any impact on bank efficiency in Indonesia? A two-stage analysis. Applied Economics, 48(52), 5060-5074. https://doi.org/10.1080/00036846.2016. 1170934

Defung, F., et al. (2018). The Impact of Economic Turbulence on Local Bank Efficiency: Does Common Wisdom Hold? 35(Miceb 2017), 1-5. https://doi.org/10.2991/miceb17.2018.1

Dianti, D.W. (2019). Analisis Efisiensi teknis pada Initial Public Offering (IPO) Panin Dubai Syariah Bank. Thesis. Institut Pertanian Bogor.

Endri. (2009). Penguatan Stabilitas Sistem Keuangan Melalui Peningkatan Fungsi Intermediasi Dan Efisiensi Bank Pembangunan Daerah (BPD). Jurnal Keuangan Dan Perbankan, 13(1), 120134.

Eyceyurt Batir, T., et al. (2017). Determinants of bank efficiency in Turkey: Participation banks versus conventional banks. Borsa Istanbul Review, 17(2), 86-96. https://doi.org/10.1016/j.bir.2017.02.00 3

Fadhlullah, A. H. (2015). Efisiensi Bank Pembangunan Daerah: Pendekatan Stochastic Frontier. Signifikan: Jurnal IImu Ekonomi, 4(1), 1-16. https://doi.org/10.15408/sjie.v4i1.2291

Financial Services Authority. (2009). Indonesian Banking Statistic.

Farrell, M. J. (1957). The Measurement of Productive Efficiency http://www.jstor.org/stab. Journal of the Royal Statistical Society. Series $A$ (General), 120(3), 253-290. http://goo.gl/AFhm2N

Firdaus, M. et al. (2014). Efisiensi Bank Umum Syariah Menggunakan Pendekatan Two-
Vol. 6 No. 2, Des 2020, Hal. 171-186 P-ISSN: 2502-1400, E-ISSN: 2502-5678

Stage Data Envelopment Analysis. Buletin Ekonomi Moneter Dan Perbankan, 16(2), 167-188.

https://doi.org/10.21098/bemp.v16i2.31

Garza-García, J. G. (2012). Determinants of bank efficiency in Mexico: A two-stage analysis. Applied Economics Letters, 19(17), 1679-1682. https://doi.org/10.1080/13504851.2012. 665589

Ghofur, A., and Sukmaningrum, P. S. (2018). Pegaruh Good Corporate Governance Terhadap Efisiensi Bank Syariah Tahun 2012-2016 Dengan Kinerja Sosial Sebagai Variabel Intervening. Jurnal Ekonomi Dan Bisnis Islam (Journal of Islamic Economics and Business), 4(1), 30. https://doi.org/10.20473/jebis.v4i1.1004 7

Girardone, C., et al. (2004). Analysing the determinants of bank efficiency: The case of Italian banks. Applied Economics, 36(3), 215-227. https://doi.org/10.1080/0003684042000 175334

Gordo, G. M. (2013). Estimating Philippine Bank Efficiencies Using Frontier Analysis. Philippine Management Review, 20, 1736.

Hadad, M. D., et al. (2012). A new approach to dealing with negative numbers in efficiency analysis: An application to the Indonesian banking sector. Expert Systems with Applications, 39(9), 82128219.

https://doi.org/10.1016/j.eswa.2012.01. 145.

Hadad, M. D., et al. (2003). Analisis Efisiensi Industri Perbankan BI. Journal of Economics Literature. https://www.bi.go.id/id/publikasi/perba nkan-danstabilitas/riset/Pages/Penggunaan Metode Nonparametrik Data Envelopment Analysis (DEA).aspx. 
Anneke Puspasari: Bank Specific Factors ...

Hasibuan, S. P. (1994). Manajemen Perbankan. Jakarta: CV Haji Magum.

Hauner, D. (2005). Explaining efficiency differences among large German and Austrian banks. Applied Economics, 37(9), 969-980.

https://doi.org/10.1080/0003684050008 1820.

Hou, X., et al. (2014). Market structure, risk taking, and the efficiency of Chinese commercial banks. Emerging Markets Review, 20, 75-88. https://doi.org/10.1016/j.ememar.2014. 06.001 .

Hughes, J. P., and Mester, L. J. (1993). A quality and risk-adjusted cost function for banks: Evidence on the "too-big-to-fail" doctrine. Journal of Productivity Analysis, 4(3), 293315. https://doi.org/10.1007/BF01073414.

Isik, I., and Hassan, M. K. (2003). Efficiency, ownership and market structure, corporate control and governance in the Turkish banking industry. Journal of Business Finance and Accounting, 30(910), 1363-1421. https://doi.org/10.1111/j.0306686X.2003.05533.x.

Irawati L. (2008). Pengukuran tingkat efisiensi bank umum syariah di indonesia dan analisis beberapa faktor penentu. tesis. Universitas Indonesia.

Karim, M. Z. A., et al. (2010). Bank efficiency and non-performing loans: Evidence from malaysia and Singapore. Prague Economic Papers, 2, 118-132. https://doi.org/10.18267/j.pep.367.

Lotto, J. (2019). Evaluation of factors influencing bank operating efficiency in Tanzanian banking sector. Cogent Economics and Finance, 7(1). https://doi.org/10.1080/23322039.2019. 1664192.

Mamatzakis, E., et al. (2016). What is the impact of bankrupt and restructured loans on Japanese bank efficiency? Journal of Banking and Finance, 72, S187-
S202.

https://doi.org/10.1016/j.jbankfin.2015. 04.010 .

Maniati, M., and Sambracos, E. (2017). Measuring the Technical Efficiency for the Shipping Banks-An Approach Using Data Envelopment Analysis. Theoretical Economics Letters, 07(03), 502-516. https://doi.org/10.4236/tel.2017.73038.

Mokhtar, H. S. A., et al. (2008). Efficiency and competition of Islamic banking in Malaysia. Humanomics, 24(1), 28-48. https://doi.org/10.1108/0828866081085 1450.

Muljawan, D., et al. (2014). Faktor-Faktor Penentu Efisiensi Perbankan Indonesia serta Dampaknya terhadap Perhitungan Suku Bunga Kredit. Working Paper Bank Indonesia, WP/2/2014, 1-77.

Pasiouras, F. (2008). Estimating the technical and scale efficiency of Greek commercial banks: The impact of credit risk, offbalance sheet activities, and international operations. Research in International Business and Finance, 22(3), 301-318. https://doi.org/10.1016/j.ribaf.2007.09.0 02.

Peni, E., and Vähämaa, S. (2012). Did Good Corporate Governance Improve Bank Performance during the Financial Crisis? Journal of Financial Services Research, 41(1-2), 19-35. https://doi.org/10.1007/s10693-0110108-9.

Rosman, R., et al. (2014). Efficiency of Islamic banks during the financial crisis: An analysis of Middle Eastern and Asian countries. Pacific Basin Finance Journal, 28, 76-90. https://doi.org/10.1016/j.pacfin.2013.11. 001.

Santosa, B. (2018). A Comparative Study of Banking Efficiency between Indonesia and Thailand in the Post Asian Monetary Crisis. Dissertation. The Maastricht School of Management.

Sathye, M. (2012). The Impact of Financial Crisis 
on Superannuation Funds Efficiency: Evidence from Australia. SSRN Electronic Journal, 10(2). https://doi.org/10.2139/ssrn.1944427.

Sherman, H. D., and Zhu, J. (2006). Service productivity management: Improving service performance using data envelopment analysis (DEA). In Service Productivity Management: Improving Service Performance using Data Envelopment Analysis (DEA). https://doi.org/10.1007/0-387-33231-6.

Spong, K., et al. (1995). What Makes a Bank Efficient? A Look at Financial Characteristics and Bank Management and Ownership Structure. Financial and Industry Perspectives: Federal Reserve Bank of Kansas City, 1-19.

Sufian, F. (2009). Determinants of bank efficiency during unstable macroeconomic environment: Empirical evidence from Malaysia. Research in International Business and Finance, 23(1), 54-77.

https://doi.org/10.1016/j.ribaf.2008.07.0 02.

Sufian, F., et al. (2016). Determinants of efficiency in the malaysian banking sector: Does bank origins matter? Intellectual Economics, 10(1), 38-54. https://doi.org/10.1016/j.intele.2016.04. 002.

Sutanto, H. A. (2015). Analisis Efisiensi Teknis Bank Pembangun. Jejak, 8(1), 23-35. https://doi.org/10.15294/jejak.v8i1.3851

Tobing, A., et al. (2013). Pengaruh Penerapan Good Corporate Governance terhadap Tingkat Kesehatan dan Daya Saing di Perbankan Indonesia. Jurnal Manajemen Teknologi, 12(3), 298-318. https://doi.org/10.12695/jmt.2013.12.3. 5.

Vistarani F. (2018). Analisis Efisiensi Bank Pembangunan Daerah Ekspansi dan Non-Ekspansi Dengan Pendekatan Data
Envelopment Analysis. Economics Development Analysis Journal, 6(3), 346351.

Vu, H., and Turnell, S. (2011). Cost and profit efficiencies of australian banks and the impact of the global financial crisis. Economic Record, 87(279), 525-536. https://doi.org/10.1111/j.14754932.2011.00760.x.

Wardhani, P. I., and Mongid, A. (2019). Strategies to increase production efficiency in Indonesian Sharia commercial banks using Stochastic Frontier Approach (SFA). Journal of Economics, Business and Accountancy Ventura, 21(3), 379. https://doi.org/10.14414/jebav.v21i3.15 97.

Weill, L. (2003). Banking efficiency in. Transition, 11(November 2000), 569-592.

Wheelock, D. C., and Wilson, P. W. (1995). Explaining bank failures: deposit insurance, regulation, and efficiency. Review of Economics and Statistics, 77(4), 689-700. https://doi.org/10.2307/2109816.

Widiarti, A. W., et al. (2015). The Determinants of Bank'S Efficiency in Indonesia. Buletin Ekonomi Moneter dan Perbankan, 18(2), 129-156.

https://doi.org/10.21098/bemp.v18i2.52 0.

Yin, H., Yang, J., and Mehran, J. (2015). Do Chinese banks perform better after IPOs? Managerial Finance, 41(4), 368-384. https://doi.org/10.1108/MF-06-20140150.

Yonnedi, E., and Rahman Panjaitan, A. (2019). Efficiency and Productivity Analysis of Indonesian Regional Development Banks: Multi-Stage Dea Approach and Malmquist Productivity Index. Jurnal Bisnis Dan Manajemen, 20(2), 145-174. https://doi.org/10.24198/jbm.v20i2.323. Yusuf M. (2018). Penyertaan modal pemerintah daerah pada bank pembangunan daerah 
di indonesia. Dissertation. Institut Pertanian Bogor. 